\title{
How Job Involvement Moderates the Relationship Between Organizational Commitment and Job Satisfaction: Evidence in Vietnam
}

\author{
Hsinkuang Chi \\ Department of Business Administration, \\ Nanhua University, Taiwan \\ Hueryren Yeh \\ Department of Marketing Management, \\ Shih Chien University, Kaoshiung, Taiwan \\ Khanh-Van Ho Nguyen \\ Ph.D Student, Dept. of Business Administration, \\ Nanhua University, Taiwan
}

\begin{abstract}
The purpose of this study is to investigate whether there are significant relationships among perceived organizational support, organizational commitment, job involvement, job commitment, and job satisfaction. The sample for this study included 275 employees in Vietnam. The findings revealed that organizational commitment had a partial mediating effect between perceived organizational support and job satisfaction. Furthermore, the study found that job involvement had a moderating effect on the relationship between organizational commitment and job satisfaction.
\end{abstract}

Keywords: Perceived Organizational Support, Organizational Commitment, Job Satisfaction, Job Involvement, Mediator, Moderator

\section{INTRODUCATION}

Today, the business environment is severely competitive; employees following this concept are viewed as one of the most important assets in an organization. It can be said that an employee is the main resource that enables the organization to be successful. With the awareness of employees' roles, modern organizations have to make efforts in order to support and take care of their employees. Employers recognize the importance of keeping employees engaged and satisfied, since it has a better effect on productivity and innovations, as well as causes a desire to remain longer with the organization. These help the organization successfully reach its objectives and strengthen their competitive position in the market. The challenges for employers now involve the issue of how to cause the employees to be satisfied with their job so that the employees may contribute to the organization. In order to do that, it is necessary for the organization to evaluate which behaviors, attitudes, or factors influence employees' job satisfaction. Therefore, the goal of this study is to investigate whether or not perceived organizational support, organizational commitment, and job involvement significantly affect job satisfaction.

In the field of organizational research, job satisfaction, perceived organizational support, organizational commitment, and job involvement are the most common subjects measured, and the relationships among them are also a concern. Several studies found that 
organizational support and the relationship between employer and employee affect employees' satisfaction (Karrasch, 2003; Karsh, Booske, \& Sainfort, 2005) and organizational commitment (Karrarsch, 2003). The level of the organizational commitment is affected by employees' perception of organizational support and security of employment with an organization (Chen, Lin, Lu, \& Taso, 2007; Kacmar, Witt, Zivnuska, \& Gully, 2003); the more satisfaction and commitment the employees have, the more successful the organization will be in reaching their goals and gaining a competitive advantage. Mowday, Porter, and Steers (1982) argued that without a significant level of employee commitment, an organization will not survive. Business organizations are all focused on increasing organizational productivity or making more of a profit; therefore, it is necessary to evaluate which factors influence an employee's commitment the most (Meyer \& Allen, 1997; Chen, Silverthorne, \& Hung, 2006). Organizational support is considered one of the most important factors in maintaining employees in the organization. Employees who feel that they are supported by the organization are satisfied with their job and are attached to their organization. Previous studies proved that employees who are supported are satisfied with their job (Buchanan, 1974; Tansky \& Cohen, 2001), which improves positive behaviors and attitudes such as commitment (Eisenberger, Huntington, Hutchison, \& Sowa, 1986; Randall, Cropanzano, Borman, \& Birjulin, 1999; Rhodes \& Eisenberger, 2002).

The aim of this study is to understand the factors that drive employees to become more satisfied and committed to the organization, which could possibly help supervisors and top management to consider which actions are necessary to enhance the positive impacts of such factors. Additionally, the goal is to measure the mediating effect of perceived organizational support and organizational commitment on job satisfaction and the moderating effect of organizational commitment and job involvement on job satisfaction.

\section{Perceived Organizational Support}

\section{LITERATURE REVIEW}

According to the organizational support theory, Eisenberger et al. (1986) proposed that perceived organizational support can be viewed as the determination of the organization's willingness to reward employees' work efforts. Additionally, employees develop beliefs toward the organization; they need to know the degree to which the organization respects their contributions and cares about their well-being, in order to meet their socio-emotional needs (Eisenberger et al., 1986; Shore \& Shore, 1995). The more that organizational support is felt by the employee, the more organizational behavior the employee will have and will be willing to do more for the organization (Chen, 2008). Rhoades and Eisenberger (2002) indicated that perceived organizational support is also valued as the support available from the organization, which is necessary in improving employees' positions and dealing with stressful cases. Makanjee, Hartzer, and Uys (2006) described perceived organizational support as an organization's commitment to its employees. Those scholars also argued that perceived organizational support is the support that an employee receives from the employer to assist them in completing a required task effectively.

Shore and Wayne (1993) mentioned that the greater perceived organizational support can result in better attachment and feelings of engagement to the organization, which is rooted in the social exchange theory (Blau, 1964). An individual who works for an organization recognizes support, which is positively related to job performance (Eisenberger, Fasolo, \& Davis-LaMastro, 1990), especially job satisfaction (Eisenberger, Cummings, Armeli, \& Lynch, 1997), affective commitment (Eisenberger et al., 1990; Wayne, Shore \& Liden, 1997), and job involvement (Rhoades \& Eisenberger, 2002). Additionally, perceived organizational support might increase continuance commitment, which happens when employees remain with an organization due to the high cost of leaving. Following the organizational support theory, in 
retreating a high level of support, employees work enthusiastically to help their organization reach its goals (Aselage \& Eisenberger, 2003), because organizational support has a significant effect on job satisfaction and organizational commitment (Rhodes \& Eisenberger, 2002).

Susskind, Borchgrevink, Kacmar, and Brymer (2000) indicated that when employees perceive little or no support from their organization, they may feel that their job is displeasing, which may result in job dissatisfaction. That is, the employees remain satisfied with their job when they perceive that the organizational support is given for valuable employees in their organization. Previous studies proved that employees who are supported are satisfied with their job (Buchanan, 1974; Eisenberger et al., 1986; Tansky \& Cohen, 2001).

\section{Organizational Commitment}

According to Mowday, Steers, and Porter (1979) and Mowday et al. (1982), organizational commitment is the behavior that connects employees to the organization. In other words, it is the nature of the relationship of an employee to the whole organizational system (Grusky, 1966), or an attitude towards the organization attaching the identity of the employee to the organization. It is how an employee feels towards the organization (Price, 1997) and his/her willingness to offer their working ability and their loyalty to the whole system. Personality systems attach to social relations and are seen as self-expressive (Kanter, 1968). Organizational commitment stands for the degree that an individual adopts organizational values and goals, and matches them in fulfilling their job responsibilities (Tanriverdi, 2008). In general, organizational commitment is an attitude toward the organization and its goals which attaches the character of the person to the organization.

Wayne et al. (1997) emphasized that a high level of perceived organizational support creates a feeling of obligation, which means employees not only feel they are committed to their organization, but also sense the obligation to return the favor by putting more effort into their job. Studies examined the relationship between perceived organizational support and organizational commitment and indicated that perceived organizational support is an important factor that revealed organizational commitment (Buchanan, 1974; Eisenberger et al., 1986; Randall et al., 1999; Tansky \& Cohen, 2001; Rhodes \& Eisenberger, 2002; La Mastro, 2008; Riggle, Edmondson, \& Hansen, 2009). Rhodes and Eisenberger (2002) conducted an extensive literature review on relating factors that contribute to perceived organizational support. This study found that positive organizational support had a strong positive relationship towards affective commitment and continuance commitment, whilst a small negative relationship to normative commitment. Researchers argued that the level of employee commitment is also affected by employees' perception of organizational support and security of employment with an organization (Kacmar et al., 2003; Chen et al., 2007).

\section{Job Involvement}

According to Lodahl and Kejner (1965), in their most widely accepted definition, job involvement is defined as the degree that an employee is identified psychologically with their work. Lawler (1986) indicated that job involvement is an important element which has an impact on employee and organizational outcomes. Lawler and Hall (1970) added one more aspect: the degree to which the job is central to the employee and his total self-image because of the opportunity it provides him to satisfy important needs. Along the same line, Dubin (1956) conceptualized job involvement as the degree to which job is a "central life interest." It is considered as a meaningful source for the basic needs satisfaction. Following Kanugo (1982), job involvement is the level of central interest the job plays in a person's life; also it is individual's identification in psychology or the commitment of a person to his job. Pollock (1997) showed one more aspect of job involvement: the amount of enjoyment an employee 
expresses for his/her job. Li and Long (1999) in their study defined job involvement as the degree to which an individual or employee shows emotional or mental identification with his/her job. In general, job involvement is the degree of psychological association with the job and the importance of the job played in an employee's life.

\section{Job Satisfaction}

Job satisfaction is a major concern of business managers and executives in industry. Investigation regarding job satisfaction has been conducted in several areas and occupations. Hoppock (1935) identified job satisfaction as "a combination of psychological, physiological and environmental circumstances that causes a person to say: I'm satisfied with my job." In the industrial literature, job satisfaction is recognized as the positive emotional level gained by the employee when they get a job appraisal (Locke, 1976). In other words, job satisfaction is the pleasurable emotional state resulting from the appraisal of the employee's job as facilitating the achievement of their job values (Locke, 1969). Job satisfaction is viewed as the results of the degree to which job needs are perceived as being fulfilled on the job (Morse, 1953; Porter, 1962). Entering into the $21^{\text {st }}$ century, Weiss (2002) defined job satisfaction as a positive measurable judgment of an individual on his or her working conditions. In addition, Weiss (2002) regarded job satisfaction as an internal state which is "a positive (or negative) evaluative judgment one makes about one's job or job situation" (p.22). According to George and Jones (2008), job satisfaction is "the collection of feelings and beliefs that people have about their current jobs. People's levels of job satisfaction can range from extreme satisfaction to extreme dissatisfaction." Robbin and Judge (2009) defined job satisfaction as "a positive feeling about a job resulting from an evaluation of its characteristics." Many theories have been built to examine the influence of personality-related and work-related conditions on job satisfaction. The five-level hierarchy needs of Maslow (1954) indicated that people are satisfied from a series of needs which include physiological, security, social, self-esteem, and self-actualization. Regarding employee satisfaction, satisfaction of these needs determines the level of employee satisfaction. Herzberg (1959), in his two-factor theory, figured out two sets of job factors: motivators and hygiene factors. The former is expected to be satisfiers such as achievement, recognition, advancement, or personal growth; the latter is dissatisfiers of hygiene factors such as company policies, supervisory practices, wages/salary, and relations with peers.

According to Porter, Steers, and Mowday (1974), job satisfaction and organizational commitment are related, but there are distinguishable attitudes. The reverse also occurs where organizational commitment is the reason for job satisfaction (Vandenberg \& Lance, 1992). In other words, when an employee is satisfied with his/her job, he/she becomes more committed to the organization and visa versa. Job satisfaction can be measured and assessed by organizational commitment (Vanderberg \& Lance, 1992; Lok \& Crawford, 1999; Yiing \& Bin Ahmad, 2009). Lok and Crawford (1999), along with Yiing and Bin Ahmad (2009) found that organizational commitment was significantly associated to job satisfaction. If employees are committed to their work, they are likely to become more satisfied with their job. Employee commitment has been found to be positively and significantly correlated to positive organizational outcome in job satisfaction (Bateman \& Straaser, 1984). Job involvement is also considered a reason for organizational commitment and enhances employee performance and productivity (Mowday, et al., 1982). Overall, job satisfaction can be measured and assessed by organizational commitment (Porter et al., 1974; Vanderberg \& Lance, 1992; Young, Worchel, \& Woehr, 1998; Testa, 2001). 


\section{The Mediation of Organizational Commitment on Perceived Organizational Support and Job Satisfaction}

Organizational commitment is one of the most important outcomes in research due to its connection to many attitudinal and behavioral issues at work. High levels of employee commitment tend to increase levels of performance and productivity and decrease absenteeism, turnover, and tardiness (Porter et al., 1974). Ayers (2010) revealed a significant relationship between job satisfaction, job involvement, and organizational commitment. Judeh (2012) proved that there was a partial mediator of organizational commitment in the relationship between perceived organizational support and job satisfaction.

Today, the job market is critically competitive; hereby, there are several factors that contribute to the employee's intention to leave or stay. Employee turnover is one of the biggest challenges in human resources; it is costly and difficult for management of an organization. A review of the literature suggested that the more organizational support is perceived, and the higher committed an employee is, the more satisfied the employee will be.

\section{The Moderation of Job Involvement in Organizational Commitment and Job Satisfaction}

Organizational scholars consider job involvement an important factor; this factor influences both employees and organizational outcomes (Lawler, 1986). According to Hackett, Lapierre, and Hausdorf (2001), employees with high levels of job involvement allow the job to become the central part of their life and pay more attention to their jobs. Compared to the employees with low levels of job involvement, they are likely to have less unexcused tardiness and fewer unexcused absences (Blau, 1986; Blau \& Boal, 1987). Tiwari and Singh (2014) revealed that job involvement increased the strength of the relationship between job satisfaction and organizational commitment. In other words, when job involvement exists, it will increase the job satisfaction and organizational commitment relationship, as compared with the case where there is no job involvement.

\section{Research Framework}

\section{RESEARCH METHODS}

Based on the research purposes and literature review, this study proposes a research framework to investigate the influences of perceived organizational support, organizational commitment, and job involvement on job satisfaction (see Figure 1).

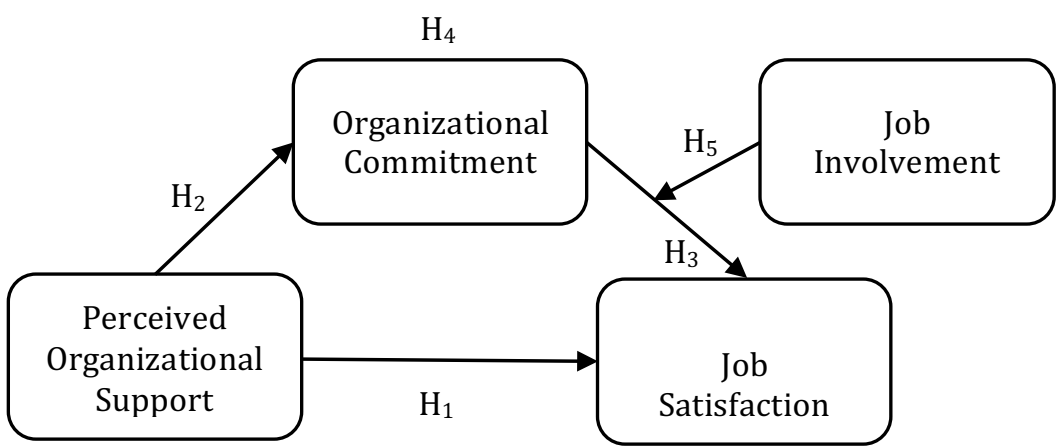

Figure 1. Research Framework

\section{Research Hypotheses}

The study proposes the research hypotheses as follows:

H1: There are relationships between perceived organizational support and job satisfaction. 
H2: There are relationships between perceived organizational support and organizational commitment.

H3: There are relationships between organizational commitment and job satisfaction.

H4: Organizational commitment will mediate the relationship between perceived organizational support and job satisfaction.

H5: Job involvement will moderate the relationship between organizational commitment and job satisfaction.

\section{Sample and Data Collection}

The research was conducted with the employees who currently work in a private sector in Ho Chi Minh City, Vietnam. In order to collect data, a questionnaire survey was completed in a convenience sampling. Items were rated on a seven-point Likert scale, ranging from "strongly disagree" to "strongly agree." The questionnaire was originally prepared in English, was then translated into Vietnamese, and was finally translated once again into English to ensure accuracy. In total, 350 employees were invited to the study and 275 valid questionnaires were collected for the analyses, resulting in a $78.6 \%$ overall response rate. The majority (51.6\%) of respondents was female and $48.4 \%$ was male. The average age of respondents ranged from 26 to 35 years old (58.9\%) and $28 \%$ were under 25 years old. Regarding education, $56 \%$ had a bachelor's degree. Additionally, $62.2 \%$ of the respondents had been working for less than five years; $23.6 \%$ had been working from 6 to 9 years; and only $4 \%$ had work experience of more than 16 years. Regarding employment, $84 \%$ of the respondents were employees and $10.5 \%$ of respondents were managers, ranging from lower-level to top managers.

\section{Measures}

The questionnaires used in the current study consisted of two main parts; the first portion concerned demographic information of the respondents and the second part involved items belonging to four constructs: perceived organizational support, job involvement, job satisfaction, and organizational commitment. Perceived organizational support was assessed using six questionnaire items developed by Eisenberger et al. (1986). To measure job involvement, six questionnaire items which were adopted based on Kanugo's study (1982) and were developed by Karacaoglu (2005). As for job involvement, five questionnaire items were adopted based on Spector (1985). To measure those kinds of commitment, four questionnaire items of each component were adopted based on the Porter et al. study (1978). All constructs in this study met the Cronbach's requirements which are recommended by Nunnally (1978). The reliabilities of these scales are all higher than 0.7 (ranged from 0.710 to 0.869 ).

\section{DATA ANALYSIS AND RESULTS}

To test the hypotheses, data analyses were performed using SPSS, version 23. Descriptive statistics and bivariate correlations among the variables in the study are shown in the Table 1.

Table 1. Descriptive statistics and bivariate correlations of the variables

\begin{tabular}{lllllll}
\hline Variables & Mean & Std. Dev & POS & OC & JS & JI \\
\hline POS & 4.601 & 1.135 & $1(.907)$ & & & \\
OC & 4.841 & 1.088 & $.739^{* * *}$ & $1(.941)$ & & \\
JS & 5.047 & 1.094 & $.675^{* * *}$ & $.820^{* * *}$ & $1(.849)$ & \\
JI & 5.263 & 1.072 & $.640^{* * *}$ & $.724^{* * *}$ & $.731^{* * *}$ & $1(.896)$ \\
\hline
\end{tabular}

Note: $1 .^{*} \mathrm{p}<0.05,{ }^{* *} \mathrm{p}<0.01,{ }^{* * *} \mathrm{p}<0.001$ (Cronbach's alpha) 
The highest mean level was involved job involvement (5.236) with a standard deviation of 1.072, while the lowest mean level was perceived organizational support (4.601) with a standard deviation of 1.135. Correlation showed that perceived organizational support positively correlated with job satisfaction $(r=0.675, p<0.001)$, and also positively correlated with organizational commitment $(\mathrm{r}=0.739, \mathrm{p}<0.001)$ supporting $\mathrm{H}_{1}$ and $\mathrm{H}_{2}$, respectively. Moreover, organizational commitment positively correlated with job satisfaction $(\mathrm{r}=0.820$, $\mathrm{p}<0.001$ ). Therefore, $\mathrm{H}_{3}$ is supported; the results are illustrated in Table 1.

Baron and Kenny's (1986) suggestion was applied to test the mediation effect $\left(\mathrm{H}_{4}\right)$. A regression analysis was utilized to examine whether organizational commitment has a mediation effect on the relationship between perceived organizational support and job satisfaction. First, the relationship between perceived organizational support (independent variable) and organizational commitment (mediator variable) was tested. The results showed that perceived organizational support was significantly and positively related to organizational commitment $(\beta=0.708, p<0.001)$ (see Model 1 ). In the second step, perceived organizational support and organizational commitment were the independent variables and job satisfaction was entered as a dependent variable. The results indicated that perceived organizational support was significantly and positively related to job satisfaction $(\beta=0.649, p<0.001)$ (see Model 2). Organizational commitment is significant and positively accounted for job satisfaction $(\beta=0.823, p<0.001)$ (see Model 2 ). Finally, perceived organizational support and organizational commitment regressed with job satisfaction $(\beta=0.146, p<0.001 ; \beta=0.710$, $\mathrm{p}<0.001$ ) (see Model 3). The results are shown in Table 2.

Table 2. Mediation test of organizational commitment between perceived organizational and job satisfaction

\begin{tabular}{lllll}
\hline \multirow{2}{*}{ Variables } & Model 1 & Model 2 & & Model 3 \\
\cline { 2 - 5 } & OC & JS & JS & JS \\
\hline POS & $.708^{* * *}$ & $.649^{* * *}$ & & $.146^{* *}$ \\
OC & & & $.823^{* * *}$ & $.710^{* * *}$ \\
R $^{2}$ & .545 & .455 & .672 & .682 \\
Adj-R & .544 & .453 & .671 & .680 \\
F & 327.565 & 227.104 & 556.555 & 290.840 \\
\hline
\end{tabular}

Note: $1 .^{*} \mathrm{p}<.05,{ }^{* *} \mathrm{p}<.01,{ }^{* * *} \mathrm{p}<.001, \beta=$ Unstandardized coefficient.

2. POS: Perceived organizational support, OC: Organizational commitment, JS: Job satisfaction

The mediation test results showed that $\beta$ value of perceived organizational support was reduced from 0.649 to 0.146 , and both perceived organizational support and organizational commitment were significantly related to job satisfaction. Therefore, hypotheses four $\left(\mathrm{H}_{4}\right)$ was supported. Organizational commitment provides a partial mediation effect on the relationship between perceived organizational support and job satisfaction.

Additionally, the study followed Preacher and Hayes (2004)'s suggestion to test the indirect effect of organizational commitment. The Sobel test and the bootstrap approach confidence intervals (CIs) were also applied to verify mediating effects. The results showed that the Sobel test is significant $(\mathrm{p}=0.000<0.001)$. The $\mathrm{z}$-value equals to 11.0198 , which is greater than 1.645 $(\mathrm{p}<0.05)$, and the value of the mediating effect is 0.5029 . This indicates that there is a mediating effect. The study further uses the bootstrap method to examine the Sobel test. It shows that CIs are between 95\% and 5\% (excluding 0), reaching significant levels (See Table $3)$. Therefore, the results also support $\mathrm{H}_{4}$. 
Table 3. Regression analysis of the indirect effect between perceived organizational support and job satisfaction

\begin{tabular}{|c|c|c|c|c|c|}
\hline \multicolumn{6}{|c|}{ Direct Effects and Total Effect } \\
\hline & & $\mathrm{B}$ & SE & $\mathrm{t}$ & $\mathrm{p}$ \\
\hline \multicolumn{2}{|c|}{ IV $\rightarrow$ DV } & .6489 & .0431 & 15.0700 & .0000 \\
\hline \multicolumn{2}{|c|}{$\mathrm{IV} \rightarrow \mathrm{MV}$} & .7080 & .0391 & 18.0890 & .0000 \\
\hline \multicolumn{2}{|c|}{$\mathrm{MV} \rightarrow \mathrm{DV}, \mathrm{DV}$ is controlled } & .7103 & .0510 & 13.9173 & .0000 \\
\hline \multicolumn{2}{|c|}{ IV $\rightarrow$ DV, MV is controlled } & .1460 & .0489 & 2.9866 & .0031 \\
\hline \multicolumn{6}{|c|}{ Indirect effect and significance using the normal distribution } \\
\hline & Value $\quad$ SE & LL95\%CI & UL95\%CI & $\mathrm{z}$ & $\mathrm{p}$ \\
\hline & & .4135 & .5923 & 11.0198 & .0000 \\
\hline \multicolumn{6}{|c|}{ Bootstrap results for indirect effect } \\
\hline & Value $\quad$ SE & LL95\%CI & UL95\%CI & Mean & \\
\hline Effect & .5029 & .3862 & 6209 & .5002 & \\
\hline
\end{tabular}

Note: 1. IV: Independent variable (Perceived organizational support), DV: Dependent variable (Job satisfaction), MV: Mediating variable (Organizational commitment).

2. N: 274, Number of bootstrap resamples: 5000, LL=Lower limit, CI=Confidence interval, UL=upper limit

3. $\beta=$ Unstandardized coefficient.

The study also applied hierarchical regression analysis to test the research hypothesis which focused on the moderating effect of job involvement and the relationship between organizational commitment and job satisfaction. Baron and Kenny's (1986) procedures were adopted by inserting an independent variable, moderating variable, and interactive effect variable (independent*moderating variable) to predict the dependent variable. As shown in Table 4, Model 1 discloses that organizational commitment $(\beta=0.820, p<0.001)$ is positively and significantly related to job satisfaction. Model 2 shows that job involvement $(\beta=0.731$, $\mathrm{p}<0.001$ ) is positively and significantly related to job satisfaction. The results in Model 3 show that both independent variables (organizational commitment, $\beta=0.610, p<0.001$ ) and moderating variables (job involvement, $\beta=0.290, \mathrm{p}<0.001$ ) are significantly related to the dependent variable (job satisfaction) respectively. In addition, the results in Model 4 reveal that the interaction effect $\left(R^{2}=0.716, \beta=-0.088, p<0.05\right)$ of organizational commitment and job involvement is also significant to job satisfaction. This shows that job involvement plays the role of a moderator in the relationship between organizational commitment and job satisfaction. Therefore, hypothesis five $\left(\mathrm{H}_{5}\right)$ is supported. 
Table 4. The moderating effect of job involvement on the relationship between organizational commitment and job satisfaction

\begin{tabular}{lllll}
\hline & Model 1 & Model 2 & Model 3 & Model 4 \\
\cline { 2 - 5 } & JS & JS & JS & JS \\
\hline Independent Variable & $.820^{* * *}$ & & $.610^{* * *}$ & $.608^{* * *}$ \\
OC & & & \\
JI & & $.731^{* * *}$ & $.290^{* * *}$ & $.237^{* * *}$ \\
Interaction Variable & & & \\
OC*JI & & & \\
N & 275 & 275 & 275 & 275 \\
Max VIF & 1.000 & 1.000 & 1.000 & 1.000 \\
F-value & 556.555 & 312.250 & 334.407 & 227.388 \\
$\mathrm{R}^{2}$ & .672 & .534 & .712 & .716 \\
Adj. R & .671 & .533 & .710 & .713 \\
\hline
\end{tabular}

Note: $1 .^{*} \mathrm{p}<.05,{ }^{* *} \mathrm{p}<.01,{ }^{* * *} \mathrm{p}<.001$;

2. JS: Job satisfaction, OC: Organizational commitment; JI: Job involvement

In order to understand more about the moderating effect of job involvement, the study plotted the results using the same method shown in Aiken and West's study (1991). In the graph presented in Figure 2, the study showed the effects of job involvement on job satisfaction for two levels of job involvement, low and high. As can be seen in the reinforcement interaction effect in Figure 2, when employees have high job involvement, it will enforce the relationships between organizational commitment and job satisfaction. Similarly, employees with low job involvement also influence the relationships between organizational commitment and job satisfaction.

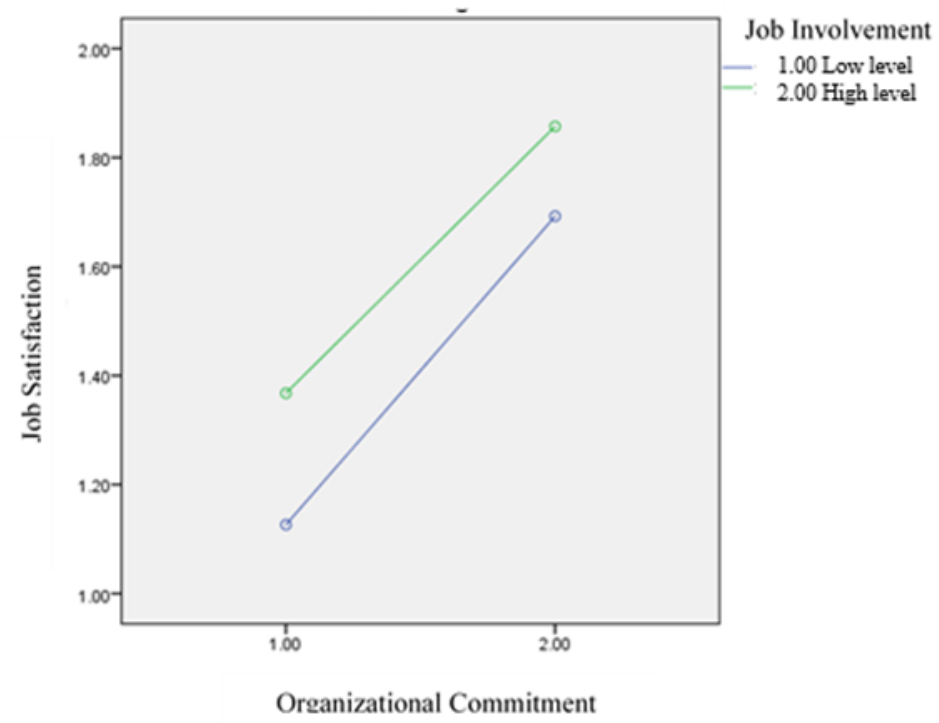

Figure 2. Reinforcement interaction effects of job satisfaction, organizational commitment, and job involvement 


\section{Findings}

\section{FINDINGS AND RECOMMENDATIONS}

By sample analysis, it was found that perceived organizational support has a significant effect on job satisfaction which means that employees who feel that they are supported by their organization are satisfied with their job. This finding is aligned with research by Buchanan (1974), Eisenberger et al. (1986), and Susskind et al. (2000). The findings revealed that perceived organizational support has a significantly positive effect on organizational commitment, which is in line with the study of Allen, Shore, and Griffeth, (2003). In other words, the more the employees receive support from an organization, the more attached to the organization they will be. These study results are also congruent with the previous findings, in which organizational commitment was significantly associated with job satisfaction. Judeh (2012) indicated that when employees are committed to the organization, they are likely to be more satisfied with their jobs and willing to do more for the organization.

The findings of the current study shed the light on the role of organizational commitment as a mediator between the relationship between perceived organizational support and job satisfaction. Due to the important role of employees' commitment and satisfaction in improving employees' behavior, it's essential for an organization to measure the organizational commitment and job satisfaction levels to have them reach their goals and benchmark with other organizations.

This study proved that job involvement does moderate the relationship between organizational commitment and job satisfaction. Organizational commitment and job involvement have a positive effect on job satisfaction. Job satisfaction will increase, following the increase of job involvement. However, comparing low levels of organizational commitment with high levels of employees' organizational commitment, their job involvement will cause the increased level of job satisfaction to be reduced. That is, the influence of low level job involvement on job satisfaction is higher than high level job involvement on job satisfaction.

\section{Recommendations}

Perceived organizational support can satisfy employees' required feelings of attachment and organizational feeling attachment can create positive emotions. Additionally, organizational commitment has a moderate effect and plays an enforcement role. The higher the organizational commitment is, the better the job involvement will be, which can increase job satisfaction effect. This is true especially when it can influence those who have a low job involvement to increase their job satisfaction. Therefore, an organization can provide employees' job resources, job empowerment, and incentives. By doing so, it can not only enforce employees' perceived organizational support, organizational commitment, and increase job satisfaction.

\section{References}

Aiken, L. S., \& West, S. G. (1991). Multiple regression: Testing and interpreting interaction. Thousand Oaks, CA: Sage.

Allen, D. G., Shore, L. M., \& Griffeth, R. W. (2003). The role of perceived organizational support and supportive human resource practices in the turnover process. Journal of Management, 29(1), 99-118.

Aselage, J., \& Eisenberger, R. (2003). Perceived organizational support and psychological contracts: A theoretical integration. Journal of Organization Behavior, 24(5), 491-509.

Ayers, J. P. (2010). Job satisfaction, job involvement, and perceived organizational support as predictors of organizational commitment (Doctoral dissertation). Walden University. (UMI no. 3397132).

Baron, R. M., \& Kenny, D. A. (1986). The moderator-mediator variable distinction in social psychological research: Conceptual, strategic, and statistical consideration. Journal of Personality and Social Psychology, 51(6), 1173-1182. 
Chi, H., Yeh, H., \& Nguyen, K, H. (2018). How Job Involvement Moderates the Relationship Between Organizational Commitment and Job Satisfaction: Evidence in Vietnam. Advances in Social Sciences Research Journal, 5(4) 136-148.

Bateman, T., \& Straaser, S. (1984). A longitudinal analysis of the antecedents of organizational commitment. Academy of Management Journal, 21, 95-112.

Blau, G. J. (1986). Job involvement and organizational commitment as interactive predictors of tardiness and absenteeism. Journal of Management, 12(4), 577-584.

Blau, G. J., \& Boal, K. B. (1987). Conceptualizing how job involvement and organizational commitment affect turnover and absenteeism. Academy of Management Review, 12(2), 288-300.

Blau. P. M. (1964). Exchange and power in social life. New York, NY: Wiley and Sons.

Buchanan, B. (1974). Building organizational commitment: The socialization of managers in work organizations. Administrative Science Quarterly, 19(4), 533-546.

Chen, C. C. (2008). Test of a mediating model linking perceived organizational support and job performance. Journal of Management and Business Research, 25(3), 309-331.

Chen, J., Silverthorne, C., \& Hung, J. (2006). Organizational communication, job stress, organizational commitment, and job performance of accounting professionals in Taiwan and America. Leadership \& Organizational Development Journal, 27(4), 242-249.

Chen, S., Lin, P., Lu, C., \& Taso, C. (2007). The moderation effect of HR strength on the relationship between employee commitment and job performance. Social Behavior and Personality, 35(8), 1121-1138.

Dubin, R. (1956). Industrial workers' worlds: A study of the central life interests of industrial workers. Social Problem, 4, 252-266.

Eisenberger, R., Cummings, J., Armeli, S., \& Lynch, P. (1997). Perceived organizational support, discretionary treatment, and job satisfaction. Journal of Applied Psychology, 82(5), 812-820.

Eisenberger, R., Fasolo, P., \& Davis-LaMastro, V. (1990). Perceived organizational support and employee diligence, commitment, and innovation. Journal of Applied Psychology, 75, 51-59.

Eisenberger, R., Huntington, R., Hutchison, S., \& Sowa, D. (1986). Perceived organizational support. Journal of Applied Psychology, 71(3), 500-507.

George, J. M., \& Jones, G. R. (2008). Understanding and managing organizational behavior ( $5^{\text {th }}$ ed.). Upper Saddle River, NJ: Pearson Prentice Hall.

Grusky, O. (1966). Career mobility and organizational commitment. Administrative Science Quarterly, 10(4), 488503.

Hackett, R. D., Lapierre, L. M., \& Hausdorf, P. A. (2001). Understanding the links between work commitments constructs. Journal of Vocational Behavior, 58, 392-413.

Herzberg, F., Mausner, B., \& Snyderman, B. B. (1959). The motivation to work (2nd ed.). New York, NY: John Wiley \& Sons.

Hoppock, R. (1935). Job satisfaction. New York, NY: Harper and Brother.

Judeh, M. (2012). Mediating effects of organizational commitment on the relationship between perceived organizational support and job satisfaction. Presented at Advances in Business-Related Scientific Research Conference, Venice.

Kacmar, K. M., Witt, L. A., Zivnuska, S., \& Gully, S. M. (2003). The interactive effect of leader-member exchange and communication frequency on performance ratings. Journal of Applied Psychology, 88(4), 764-772.

Kanter, R. M. (1968). Commitment and social organizations: A study of commitment mechanisms in Utopian communities. American Sociological Review, 33(4), 499-517.

Kanungo, R. N. (1982). Measurement of job and work involvement. Journal of Applied Psychology, 67(3), 341-349.

Karrasch, A. I. (2003). Antecedents and consequences of organizational commitment. Military Psychology, 15(3), 225-236.

Karsh, B., Booske, B. C., \& Sainfort, F. (2005). Job and organizational determinants of nursing home employee commitment, job satisfaction and intent to turnover. Ergonomics, 48(10), 1260-1281.

LaMastro, V. (2008). Commitment and perceived organizational support. National Forum, 19(1).

Lawler, E. (1986). High involvement management. San Francisco, CA: Jossey-Bass. 
Lawler, E. E., \& Hall, D. T. (1970). Relationship of job characteristics to job involvement, satisfaction, and intrinsic motivation. Journal of Applied Psychology, 54(4), 305-312.

Li, Y., \& Long, L. (1999). A literature review on job involvement. Social Psychological Research, 4, 57-63.

Locke, E. A. (1969). What is job satisfaction? Organizational Behavior and Human Performance, 4, 309-336.

Locke, E. A. (1976). The nature and causes of job satisfaction. In M.D. Dunnette (Ed.), Handbook of industrial and organizational psychology (1297-1349). Chicago, IL: Rand McNally.

Lodahl, T. M., \& Kejner, M. (1965). The definition and measurement of job involvement. Journal of Applied Psychology, 49(1), 24-33.

Lok, P., \& Crawford, J. (1999). The relationship between commitment and organizational culture, subculture, leadership style and job satisfaction in organizational change and development. Leadership \& Organizational Development Journal, 20(7), 365-373.

Makanjee, R.C., Hartzer, Y., \& Uys, I. (2006). The effect of perceived organizational support on organizational commitment of diagnostic imaging radiographers. Radiography, 12(2), 118-126.

Maslow, A. H. (1954). Motivation and personality. New York, NY: Harper.

Meyer, J. P., \& Allen, N. J. (1997). Commitment in the workplace: Theory research, and application. Thousand Oaks, CA: Sage Publishing.

Morse, N. C. (1953). Satisfactions in the white collar job. Ann Arbor: University of Michigan Survey Research Center.

Mowday, R. T., Porter, L. W., \& Steers R. M. (1982). Employee-organizational linkages: The psychology of commitment, absenteeism, and turnover. San Diego, CA: Academic Press.

Mowday, R. T., Steers, R. M., \& Porter, L. (1979). The measurement of organizational commitment. Journal of Vocational Behavior, 14, 224-247.

Nunnally. J. C. (1978). Psychometric theory. New York, NY: McGraw-Hill.

Pollock, T. (1997). Building employee's interest in their work. Automotive Manufacturing \& Production, 109(10), 10.

Porter, L. W. (1962). Job attitudes in management: I. Perceived deficiencies in need fulfillment as a function of job level. Journal of Applied Psychology, 46(6), 375-384.

Porter, L. W., Steers, R. M., \& Mowday, R. T. (1974). Organizational commitment, job satisfaction and turnover among psychiatric technicians. Journal of Applied Psychology, 59(5), 603-609.

Preacher, K. J., \& Hayes, A.F. (2004). SPSS and SAS procedures for estimating indirect effects in simple mediation models. Behavior Research Methods, Instruments, and Computers, 36(4), 717-731.

Price, J. L. (1997). Handbook of organizational measurement. Bradford, UK: MCB University Press.

Randall, M. L., Cropanzano, R., Borman, C. A., \& Birjulin, A. (1999). Organizational politics and organizational support as predictors of work attitudes, job performance, and organizational citizenship behavior. Journal of Organizational Behavior, 20(2), 159-174.

Rhoades, L., \& Eisenberger, R. (2002). Perceived organizational support: A review of the literature. Journal of Applied Psychology, 87(4), 698-714.

Riggle, R. J., Edmondson, D. R., \& Hansen, J. D. (2009). A meta-analysis of the relationship between perceived organizational support and job outcomes: 20 years of research. Journal of Business Research, 62(10), 1027-1030.

Robbins, S. P., \& Judge, T. A. (2009). Organizational behavior. Upper Saddle River, NJ: Pearson Prentice Hall.

Shore, L. M., \& Shore, T. H. (1995). Perceived organizational support and organizational justice. In R. Cropanzano \& K. Kacmar (Eds.), Organizational politics, justice, and support (pp. 149-164). Westport, CT: Quorum.

Shore, L. M., \& Wayne, S. J. (1993). Commitment and employee behavior: Comparison of affective commitment and continuance commitment with perceived organizational support. Journal of Applied Psychology, 78(5), 774-780.

Spector, P. E. (1985). Measurements of human service staff satisfaction: Development of the job satisfaction survey. American Journal of Community Psychology, 13(6),

693-713. 
Susskind, A. M., Borchgrevink, C. P., Kacmar, K. M., \& Brymer, R. A. (2000). Customer service employees' behavioral intentions and attitudes: An examination of construct validity and a path model. International of Hospitality Management, 19(1), 53-77.

Tansky, J. W., \& Cohen, D. J. (2001). The relationship between organizational support, employee development, and organizational commitment: An empirical study. Human Resource Development Quarterly, 12(3), 285-300.

Tanriverdi, H. (2008). Workers' job satisfaction and organizational commitment: Mediator variable relationship of organizational commitment factors. Journal of American Academy of Business, 14(1), 152-163.

Testa, M. R. (2001). Organizational commitment, job satisfaction, and effort in the service environment. The Journal of Psychology, 135(2), 226-236.

Tiwari, V., \& Singh, S. K. (2014). Moderation effect of job involvement on the relationship between organizational commitment and job satisfaction, SAGE Open, 1-7.

Vandenberg, R. J., \& Lance C. E. (1992). Examining the causal order of job satisfaction and organizational commitment. Journal of Management, 18(1), 153-167.

Wayne, S. J., Shore, L. M., \& Liden, R. C. (1997). Perceived organizational support and leaders-member exchange: A social exchange perspective. Academy of Management Journal, 40(1), 82-111.

Weiss, H. M. (2002). Deconstructing job satisfaction: Separating evaluations, beliefs, and affective experiences. Human Resource Management Review, 12(2), 173-194.

Yiing, L. H., \& Bin Ahmad, K. Z. (2009). The moderating effects of organizational culture on the relationships between leadership behavior and organizational commitment and between organizational commitment and job satisfaction and performance. Leadership \& Organization Development Journal, 30(1), 53-86.

Young, B. S., Worchel, S., \& Woehr, D. (1998). Organizational commitment among public service employees. Public Personnel Management, 27(3), 339-348. 